\title{
Biodegradation of COD in Household Wastewater with Aerobic Biofilm Technology by Adding Sediment Drainage Sewerage
}

\author{
Sri Sumiyati ${ }^{1 *}, P$. Purwanto ${ }^{2}$, Endro Sutrisno $^{3}, S$. Sudarno $^{3}$, Jalu Arthawidya ${ }^{3}$ and Humam Izzudin $^{3}$ \\ ${ }^{1}$ Doctoral Program of Environmental Sciences, School of Post Graduate, Diponegoro University, Semarang, Indonesia \\ ${ }^{2}$ Department of Chemical Engineering, Faculty of Engineering, Diponegoro Univers ity, Semarang, Indonesia \\ ${ }^{2}$ Department of Environmental Engineering, Faculty of Engineering, Diponegoro University, Semarang, Indonesia
}

\begin{abstract}
Household wastewater contains contaminants that harm the environment. One of the pollutants found COD. If being discharged into the environment directly, COD concentrations exceeding the existing quality standard will disrupt the ecosystem in the receiving water body. One of the technologies that can degrade COD is biofilm technology with honeycomb tube media. This research aims to analyze the decrease of COD concentration present in wastewater household with biofilm technology of honeycomb media. The reactor used in was made of glass with a thickness of $4 \mathrm{~mm}$, a volume of 18 litres and operated continuously. The media used is made of a PVC pipe, cut to $3 \mathrm{~cm}$ in size and then glued to one another, forming a honey comb. The results showed that there has been a decrease in COD concentration of household wastewater.
\end{abstract}

\section{Introduction}

Household wastewater is a very important issue recently. If it is not well managed and in right ways, it will be harmful to the environment. Household wastewater contains numerous organic pollutants, such as Biological Oxygen Demand (BOD) and Chemical Oxygen Demand (COD). Besides, it exists other pollutants, i.e. TSS, Ammoniac, Phosphate, $\mathrm{pH}$, temperature, and fat. The existence of pollutant's parameter in the household wastewater is if the concentration is over the specified standard, it will bring negative impact to the balance of ecosystem of nature. That is why the household wastewater needs to be proceeded first before being drained into the environment. One of the household wastewater treatments is by biological wastewater treatment. Biological wastewater treatment is divided into two, i.e. anaerobic and aerobic. One kind of biological wastewater treatments is biofilter and biofilm technology.

Biofilter and biofilm technology are wastewater treatment technology by using the microorganism activities, where those microorganisms attach on the surface of a medium and form biofilm layer. According to [1] biofilm layer was alive bacterial community and stuck on the surface of abiotic. Biofilm technology had numerous advantages than other types of treatments. According to [2] biofilm technology had numerous advantages compared to the suspension system and active mud. According to [3] biofilm technology had a high tolerance to the shock loading.

In this research, we chose biofilm technology due to the consideration that it was efficient and effective technology to decrease the pollutant parameter of household wastewater. Median that was used in this research was honey comb tube. Consideration using honey comb tube as a median was because it was resistant to clogging and had large specific surface area. Some researchers who had used bio-filter technology and honey comb tube as median were [4] reported that bio-filter technology of honey comb tube could reduce the wastewater COD of chicken slaughterhouse up to 78$87 \%$. The aim of this study was to analyze the efficiency of COD decreasing on the household wastewater by using biofilm technology in aerobic condition.

\section{Material and Methods}

\subsection{Synthetic Wastewater}

The wastewater that was used in this research was synthetic wastewater, with the material compositions as follow: skim powder, $\mathrm{K} 2 \mathrm{PO} 4, \mathrm{NH} 4 \mathrm{CI}$ and fresh water. Those materials include the materials of Pro Analysis (PA) standard that were bought on Laboratory supply store. This synthetic household wastewater COD was set on concentration $543.12 \mathrm{mg} / \mathrm{I}$.

\subsection{Biofilter Media}

Biofilter media that was used in this research was created from PVC pipes with the diameter $1 / 2$ inch, and those PVC pipes were cut $5 \mathrm{~cm}$ long. PVC pipes that had been cut off were glued together and formed becoming media that resembled honey comb tube. The biofilter

\footnotetext{
Corresponding author: srisumiyati71@gmail.com
} 
media in the form of honey comb tube was shown on Figure 1.

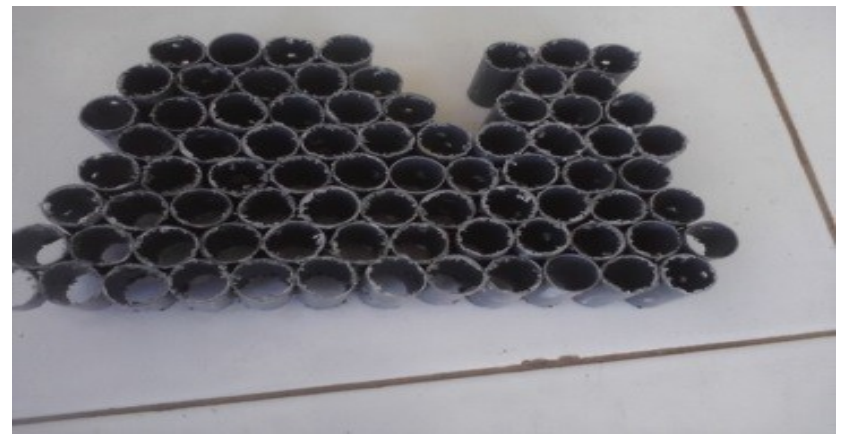

Fig. 1. Biofilter Media in a shape of Honey Comb Tube

\subsection{Research Instruments}

Table 1.The instruments in this research were shown

\begin{tabular}{|c|c|c|}
\hline No. & Description & Explanation \\
\hline 1. & $\begin{array}{cl}\text { Reactors: } \\
\text { - } \\
\text { - } \\
\text { - } & \text { Lengterials } \\
\text { - Hide } \\
\text { Height }\end{array}$ & $\begin{array}{l}\text { Glass, with the } \\
\text { thickness of } 4 \mathrm{~mm} \\
30 \mathrm{~cm} \\
20 \mathrm{~cm} \\
18 \mathrm{~cm}\end{array}$ \\
\hline 2 & $\begin{array}{l}\text { Biofilter media } \\
\text { - Materials } \\
\text { - Length of the } \\
\text { - } \text { piece } \\
\text { - } \text { Glue } \\
\text { Diameter }\end{array}$ & $\begin{array}{l}\text { PVC pipes } \\
5 \mathrm{~cm} \\
\text { Pipe glue } \\
1 / 2 \text { inch }\end{array}$ \\
\hline 3 & Inlet and outlet pipes & $\begin{array}{l}\text { PVC with the diameter } \\
\text { of } 1 / 2 \text { inch }\end{array}$ \\
\hline 4 & $\begin{array}{l}\text { Submersible pump } \\
\text { AA - } 106\end{array}$ & $\begin{array}{l}\text { Voltage: } 220-240 \mathrm{~V} \text {, } \\
\text { Frequency: } 50 / 60 \mathrm{~Hz} \text {, } \\
\text { Watt: } 85 \mathrm{~W}, \mathrm{~F} \text { Max: } \\
4000 \mathrm{~L} / \mathrm{H}, \mathrm{Hmax}: 4 \\
\text { meters }\end{array}$ \\
\hline 5 & Air Supply Aerator & $\begin{array}{l}\text { Brand: Amara, } 1 \text { hole, } \\
2.5 \text { Watt }\end{array}$ \\
\hline 6 & First Basin & $\begin{array}{l}\text { Plastic material, } \\
\text { Volume: } 200 \text { liter }\end{array}$ \\
\hline 7 & Equalization basin & $\begin{array}{l}\text { Material: Plastic, } \\
\text { Volume: } 200 \text { liter }\end{array}$ \\
\hline 8 & Discharge controller & Discharge regulator \\
\hline 9 & Last Basin & $\begin{array}{l}\text { Material: Glass, with } \\
\text { the thickness } 4 \mathrm{~mm}\end{array}$ \\
\hline
\end{tabular}

\subsection{Operational of the Reactor}

The reactor was made of glass and in shape of blocks. The reactor operation was by draining the wastewater to the first basin and then it was drained to the equalization basin. From the equalization basin, the wastewater was drained into the aerob reactor and at last, it was accommodated in the effluent basin. The design of aerob biofilm reactor used Honey Comb Tube media was shown on Figure 2.

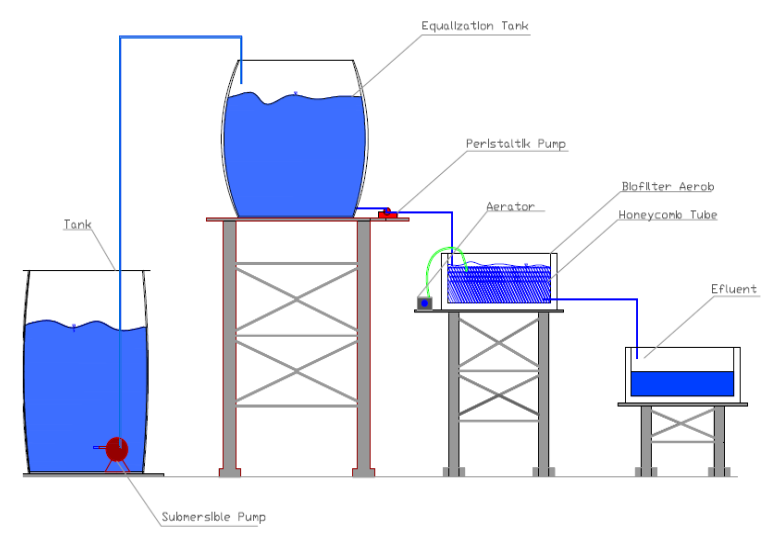

Fig. 2. Design of Aerobic Biofilm Reactor Used Honey Comb Tube

\subsection{Sample Collection}

The sample collection was done at certain points in the reactor. The collected samples were taken to the laboratory to be tested the COD concentration in the wastewater.

\section{Result and Discussion}

\subsection{Cultivation of Microorganism (Seeding Step)}

The process of microorganism cultivation was done naturally, by adding the mud in the drainage channel. Consideration to use mud addition in the drainage channel was due to the mud contained numerous microorganism that had been adapted to the condition of household wastewater. The time selected on acclimatization step was 15 th days. In those 15 th days, it was expected that the microorganism, which created biofilm layers, had begun to be mature and steady state to proceed the household wastewater continuously. The research of [5], used 10 days of the acclimatization time. [2] also reported that biofilm to reach maturity needed some days. The process in the reactor of aerob biofilm was said stable if the process run well, with the characterized by the covering of the entire bio-filter media surface by biofilm layers and happened the decreasing of COD concentration constantly. According to the physical observation inside the aerob biofilm reactor, it could be seen that on the first step of acclimatization, the biofilm layers were not formed yet, and the honey comb tube media seemed clear. After the 3rd day to 7 th day, the biofilm layer had started to be formed although not the entire surface of biofilter media had been covered. After the 7th day, which was the 8th day to 15 th day, visually it could be seen the biofilm layers that stuck on the surface of the honey comb tube media almost covered the entire surface of the media. The honey comb tube media was almost unseen, the wastewater that was drained from the aerob reactor was 
also clear and clean compared to the un-proceeded household wastewater. The efficiency of COD decreasing on the last step of acclimatization had reached stable number, which was on between 60-75 $75 \%$.

\subsection{Content of the Research}

After the step of microorganism cultivation, the next step was the reactor running step. $\mathrm{pH}$ of the wastewater on this research was set up on a range of $7.0-8.5$ and on temperature of $26-27^{\circ} \mathrm{C}$. After the biofilm layer was on steady state condition, the wastewater was then drained continuously on the discharge of $8.5 \mathrm{ml} /$ minute inside the aerob bio-filter reactor. Time to stay for wastewater in this research was set up to 12 hours. The chart of COD decreasing efficiency on the aerob reactor was shown on Figure 3.

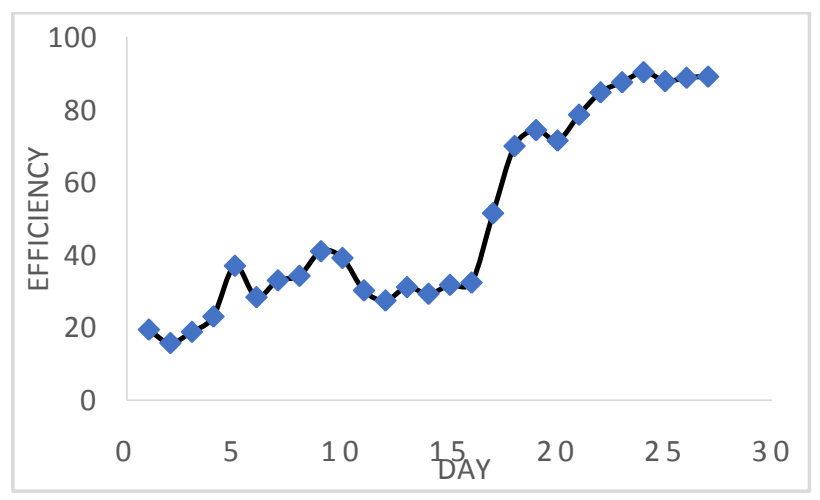

Fig. 3. Chart of COD Concentration Decreasing Efficiency

The chart of COD Concentration Decreasing Efficiency was shown on Fig 3. From that chart; it could be seen that at the first time running the reactor until the 3rd day, the value of decreasing efficiency was still low, which was less than $20 \%$. Besides, visually the wastewater was still stink and muddy. It was because of the change of the steps from acclimatization to running step, so the microorganisms that formed new biofilm layers adjusted the set-up condition on the running step, which was the incoming discharge was set continuously, including $\mathrm{pH}$ and temperature of the wastewater. As each passing day of reactor running, it seems that after the 3rd day, the efficiency value started increasing, the wastewater stink was lessen and the color had been closer to the clear. On the 15 th day (about more than 2 weeks), the value of COD concentration decreasing efficiency reached the value of about $20-30 \%$. After two weeks, the efficiency value was continue rising, the chart trend started rising, the efficiency value reached above $50 \%$. On Picture 3, it could be seen that after the 20thday, the efficiency value reached stable values, which were between $80-90 \%$. This condition showed that microorganism that formed biofilm layers had worked well. The microorganism activities that stacked on the surface of biofilter media, so the process of suspense solidity extraction and decomposition of organic compound in the wastewater run well, it was shown by the value of COD decreasing efficiency from time to time increased up to $90 \%$. Besides, the condition of wastewater that had been proceeded was not muddy and the stink was started to go.

\section{Conclusion}

Result on this research showed that the aerob biofilm technology, using honey comb tube by adding mud on the drainage channel, was able to decrease the COD concentration up to $90 \%$.

\section{References}

1. M.D. Macia, E. Rojo-Molinero and A. Oliver, Clin Microbiol Infect,20,981-990, (2014)

2. S. Anderson. Characterization of Bacterial Biofilms for Wastewater Treatment. Printed by Universitetsservice US-AB Drottning Kristinas väg 53B SE-100 44 Stockholm Sweden ISBN 978-91-7415-255-5 TRITABIO Report 2009:3 ISSN 1654-2312 (2009)

3. S. Schlegel and H. Koeser,Water Sci.Technol. 55(8-9), 83-89. (2007)

4. N.I. Said and Firly. JAI, 1, 3, Teknologi Lingkungan, BPPT Indonesia, (2005)

5. M.C. Lee, Yen-Hui Lin, Huang-Wei Yu. 2014. Biodegradation 25,849-865. DOI 10.1007/s10532-0149705-2, (2014) 